\title{
Screening Measures Used in Child Daycare Centers: A 15-Years Systematic Review
}

\author{
Alberto Filgueiras ${ }^{1,2 *}$, Pedro Pires ${ }^{3}$, J. Landeira-Fernandez ${ }^{4}$ \\ ${ }^{1}$ Department of Psychology, University of Western Ontario, London, Ontario, Canada \\ ${ }^{2}$ Department of Psychology, Pontifical Catholic University of Rio de Janeiro, Rio de Janeiro, Brazil \\ ${ }^{3}$ Institute of Psychology, Federal University of Rio de Janeiro, Rio de Janeiro, Brazil \\ ${ }^{4}$ Department of Psychology, University of Maryland, College Park, USA \\ Email: albertofilgueiras@gmail.com
}

Received 22 September 2014; revised 18 October 2014; accepted 14 November 2014

Copyright (C) 2014 by authors and Scientific Research Publishing Inc.

This work is licensed under the Creative Commons Attribution International License (CC BY).

http://creativecommons.org/licenses/by/4.0/

(c) (i) Open Access

\begin{abstract}
Childcare programs can be expensive for developing countries. To measure the efficiency of these interventions in early childhood cognitive outcomes, screening measures are proposed in this article. A systematic review was conducted to answer two questions: which are the empirical evidence available in the literature to support using psychological screening measures in child daycare centers; and if those measures can be adopted as cost-effective assessment policies for children's cognition. A total of 109 articles were retrieved. After the exclusion criteria, 18 articles remained. Ten screening measures were detected in the literature. Among those ten, three instruments were used both in child daycare centers and as assessment policies. Psychometric properties and adequacy of these measures to childcare programs are considered. Using Brazil as an example, the present article also discusses the challenges of adopting evidence-based practices in childcare policies in developing countries.
\end{abstract}

\section{Keywords}

Childcare, Screening, Cognition, Preschoolers, Early Childhood

\section{Introduction}

During early childhood, human beings face their most intense transformations in both physical and cognitive domains. This period of life is classically defined by its age range-from birth to 7 years old; and constitutes the most important phases of cognitive and emotional development. Evidences suggest that brain-home structure

${ }^{*}$ Corresponding author. 
of cognition and emotion regulation_counterbalances number of neurons and synapses from 2 to 7 years old and seems to increase the net number of synapses through these years peaking between 4 and 6 years old (Marsh, Gerber, \& Peterson, 2008).

Several authors from different fields such as economy, education and psychology try to figure which is the best way to enhance all latent cognitive potential within this age range (Christian, Morrison, \& Bryant, 1998; Claessens, 2012; Cleveland \& Krashinsky, 1998; Côté et al., 2013; Goelman et al., 2006; Herbst \& Tekin, 2010; Phillipsen, Burchinal, Howes, \& Cryer, 1997; Scarr, Eisenberg, \& Deater-Deckard, 1994). Successful projects such as the Head Start (Bergman, 1980; McKey et al., 1985), the Carolina Abecedarian Project (Ramey et al., 1984), the Chicago Child-Parent Centers (Reynolds, Temple, Robertson, \& Mann, 2002), and the Executive Functions Training Program (Diamond, Barnett, Thomas, \& Munro, 2007) show that it is possible to improve cognitive functions during early childhood. Regardless, those programs are expensive due to the number and training of professionals involved, equipment and social cost—-this last one is defined by the costs to maintain a parent (father or mother) at home and not working through their children's firsts years of development (Heckman, 2006).

If those interventions are so expensive-at least for the majority of developing countries such as Brazil, Argentina, India and China-how would poor children have access to this kind of early childhood intervention? Focusing on Brazil, 17.6\% of children within 0- to 5-years old attend to public day care centers; it represents around 3.9 million kids enrolled in public educational programs for early childhood-other children are divided into: $12.3 \%$ attending private daycare centers, and $70.1 \%$ not attending to any childcare center (Instituto Brasileiro de Geografia e Estatística, 2012). Nonetheless, Brazilian non-governmental organizations estimate that more than $32 \%$ of children who are not attending to public daycare centers also need these services in order to have adequate care, nutrition and education (Ação Educativa, 2012). On the other hand, there are no empirical evidences attesting good quality of care in public Brazilian daycare centers. Far from that, empirical data suggest that the quality of care offered by those institutions is beyond the minimum expected (de Barros, Carvalho, Franco, Mendonça, \& Rosalém, 2011; Campos, Fullgraf, \& Wiggers, 2006).

Evidence points out that investing in early childhood development is one of the best paths to achieve social equality, better income distribution and less poverty (Claessens, 2012; Cooper, 2009; Côté et al., 2013; Goodman \& Sianesi, 2005; Heckman, 2006). Children treated with good care turn into more educated adults, higher level of education means more skilled workers, and more skilled workers lead to valorization of labor and higher income to those professionals (Heckman, 2006). Thus, what appears to be a possible alternative for developing countries is to invest in already established venues and programs rather than adapting or importing other types of intervention. In other words, they are trying to make the best they can with what they have.

\section{Assessing Quality of Care and Cognition Development in Child Care Centers}

If Brazil and other developing countries are going to use their own public policies and intervention programs in childcare centers, at least they need reliable and cost-effective assessment measures to follow up the development of children attending to those projects. Currently, it appears that different instruments and measures are used to assess cognition and quality of child care. For example, measures such as ITERS and ECERS (Harms \& Clifford, 1980; Harms, Cryer, \& Clifford, 1990) assess: space and furnishing-physical aspects of the venue; education, income and training of the staff; quality of the interaction teacher-child; and program structureeducational curriculum. Studies using these measures, however, did not concern about children's cognition, thus did not use any assessment to following child development (Goelman et al., 2006; Phillipsen et al., 1997; Scarr et al., 1994). In contrast, studies focusing on cognitive and emotional variables chose to collect demographic data solely to descriptive purposes, leaving unclear which associations-if any-between children development and the physical conditions of the venue or the staff income and training would appear (Diamond et al., 2007; Rennie, Bull, \& Diamond, 2004).

Nonetheless, it seems that cognitive development has a high level of association with quality of care. For example, when children are exposed to high quality child daycare programs cognitive improvement and academic success are achieved. A program needs to present five distinct features to be considered a high quality intervention: 1) physical conditions are clean and spacious; 2) staff's overall quality (income + educational level + training) is good; 3) educational program is rich and diverse; 4) different professionals such as pediatricians, psychologists, audiologists and nutritionists follow the children's development; 5) and parents are included in 
training and interventions (Cleveland \& Krashinsky, 1998; Diamond, 2010; Hackman \& Farah, 2009; Heckman, 2006; Rolnick \& Grunewald, 2003).

Assessment measures of diverse natures are used to follow the advance of both children and policies regarding child daycare centers. Several authors highlight the importance of having a validated and empirically tested instrument to assess different domains of any intervention (Cohen \& Swerdlik, 2009; Nunnally \& Bernstein, 1994; Peter \& Churchill, 1986). Some studies in this field have proven the efficiency of combining at least one measure for cognition and another for overall quality of the child care center (Arnett, 1989; Claessens, 2012; Cleveland \& Krashinsky, 1998; Goelman et al., 2006; McLoyd, 1998), which seems to be the best way to evaluate early childhood programs.

Despite of all that, it is pivotal to look back again to developing countries and their limited budget to intervention programs. Cognitive assessment measures could be expensive to use. Intelligence batteries such as the Wechsler Preschool and Primary Scale of Intelligence-WPPSI (Wechsler, 1989) or the Stanford-Binet Intelligence Scales (Waddell, 1980) are very reliable measures for cognition in early development. Nonetheless, they are long scales and need psychologists to perform the assessment. Developing countries probably could not afford those skilled workers. Looking to Brazil as an example, it would mean evaluate 4 million children at least once a year. This assessment policy would probably not be considered cost-effective. Pondering the needs of developing countries to empirically assess the impact of their own interventions and the cost of training specialized professionals in cognitive assessment, a probable answer for a cost-effective and reliable assessment public policy would be using screening measures (Filgueiras, Pires, Maissonette, \& Landeira-Fernandez, 2013; Hunter \& Lynch, 2013; Sarmiento Campos, Squires, \& Ponte, 2011). It is important to highlight that a cognitive outcome would not replace an assessment measure for quality of staff, environment and interaction. The objective of this paper is to systematically review the psychological and the educational literature trying to answer the following questions: which are the psychological screening measures available that present reliable psychometric properties assessing children in daycare centers; and could these instruments be considered cost-effective assessment policies to evaluate cognition in developing countries?

\section{Method}

A systematic review was conducted addressing the question above. Three databases were used on these studies: 1) APA PsycNET-Psycinfo, 2) Google Scholar, and 3) Thomson Reuters' Web of Knowledge. The keywords were: i) screening; ii) measure; iii) instrument; iv) early childhood; v) pre-school; vi) early development; vii) child care; viii) day care center; and ix) child care center; combined using the following algorithm: [(i) + (ii) OR (iii) $]+[$ (iv) OR (v) OR (vi) + (vii) OR (viii) OR (ix)].

\section{Inclusion and Exclusion Criteria}

The search yielded a large number of publications that were further refined using the article title, abstract, and inclusion and exclusion criteria. Reviews, books and unpublished material such as reports, thesis, dissertations and non-published manuscripts of any kind were excluded. If a quantitative study used no standardized instruments—such as screening experimental paradigms; they were also excluded. Pediatric, dentistry, audiology and nutritional measures - not associated to mental health or psychological instruments; were also excluded, despite of the importance of those measures, they were outside the focus of the present study. Finally, only articles published within the last 15 years were included. After the examination of the exclusion criteria, all of the remaining articles were included.

\section{Results}

APA PsycNET retrived a total of 14 articles, which, after exclusion criteria applied, were reduced to 6 . Google Scholar retrieved a total of 64 papers; among them 3 were also found on APA PsycNET database. After the application of the exclusion criteria, the 64 Google Scholar's papers were reduced to 8, rather than the 3 studies retrieved by the APA PsycNET. Finally, the Thomson Reuters' Web of Knowledge database retrieved 31 studies4 of them already retrieved by APA PsycNET and other 8 also retrieved by Google Scholar. After exclusion criteria applied, only 4 remained. The established procedure retrieved a total of 18 articles -6 from APA PsycNET; 8 from Google Scholar; and 4 from Thomson Reuters' Web of Knowledge. Table 1 depicts detailed description of the results. 
Table 1. Screening measure's name, authorship and year of publication of the instrument, citations retrieved by the systematic review procedure adopted, if the measure was used in child care centers, and if the measure was used or was built to be used in assessment policies for early development.

\begin{tabular}{|c|c|c|c|c|}
\hline Screening Measure & Authors & $\begin{array}{l}\text { Studies retrieved using } \\
\text { the search procedure }\end{array}$ & $\begin{array}{l}\text { Were the study } \\
\text { conducted in } \\
\text { child care centers? }\end{array}$ & $\begin{array}{l}\text { Is this measure used } \\
\text { in assessment } \\
\text { policies in this paper? }\end{array}$ \\
\hline \multirow[t]{2}{*}{$\begin{array}{l}\text { Early Childhood Screening } \\
\text { Assessment (ECSA) }\end{array}$} & $\begin{array}{l}\text { (Gleason, Zeanah, } \\
\text { \& Dickstein, 2010) }\end{array}$ & (Gleason et al., 2010) & No & Yes \\
\hline & & (Gleason et al., 2010) & No & No \\
\hline \multirow[t]{2}{*}{$\begin{array}{l}\text { Child Behavior Checklist } \\
\text { (CBCL) }\end{array}$} & $\begin{array}{l}\text { (Achenbach \& } \\
\text { Rescorla, 1991) }\end{array}$ & (Najman et al., 2008) & No & No \\
\hline & & (Briggs-Gowan, M. J. et al., 2013) & No & No \\
\hline $\begin{array}{l}\text { Early Childhood Behavior } \\
\text { Problem Screening } \\
\text { Scale (ECBPSS) }\end{array}$ & $\begin{array}{l}\text { (Epstein \& } \\
\text { Nelson, 2006) }\end{array}$ & $\begin{array}{l}\text { (Nelson, Epstein, } \\
\text { Griffith, \& Hopper, 2007) }\end{array}$ & Yes & No \\
\hline \multirow[b]{2}{*}{$\begin{array}{l}\text { The Early Childhood } \\
\text { Inventory-4 (ECI-4) }\end{array}$} & & (Gudaitis, 2002) & No & No \\
\hline & $\begin{array}{l}\text { (Gadow \& } \\
\text { Sprafkin, 1997) }\end{array}$ & $\begin{array}{l}\text { (Sprafkin, Volpe, Gadow, } \\
\text { Nolan, \& Kelly, 2002) }\end{array}$ & No & No \\
\hline $\begin{array}{l}\text { Well-Child Check-Up } \\
\text { Revised (WCCUR) }\end{array}$ & $\begin{array}{l}\text { (Talen, Stephens, Marik, } \\
\text { \& Buchholz, 2007) }\end{array}$ & (Talen et al., 2007) & No & Yes \\
\hline \multirow[t]{3}{*}{$\begin{array}{l}\text { Developmental Indicators } \\
\text { for the Assessment } \\
\text { of Learning (DIAL) }\end{array}$} & $\begin{array}{l}\text { (Mardell-Czudnowski } \\
\text { \& Goldenberg, 1998) }\end{array}$ & (Pretti-Frontczak et al., 2002) & Yes & Yes \\
\hline & & (Filgueiras et al., 2013) & Yes & Yes \\
\hline & & (Charafeddine et al., 2013) & No & No \\
\hline \multirow[t]{2}{*}{$\begin{array}{l}\text { Ages and Stages } \\
\text { Questionnaire (ASQ) }\end{array}$} & $\begin{array}{l}\text { (Squires \& Bricker, } \\
\text { 2009) }\end{array}$ & (Juneja, Mohanty, Jain, \& Ramji, 2011) & Yes & No \\
\hline & & $\begin{array}{l}\text { (Karimi, Fallah, Dehghanpoor, } \\
\text { \& Mirzaei, 2011) }\end{array}$ & No & Yes \\
\hline \multirow{2}{*}{$\begin{array}{l}\text { Brief Infant-Toddler Social } \\
\text { and Emotional } \\
\text { Assessment (BITSEA) }\end{array}$} & $\begin{array}{l}\text { (Briggs-Gowan, M. J., } \\
\text { Carter, Irwin, Wachtel, \& }\end{array}$ & (Briggs-Gowan M. J. \& Carter, 2008) & Yes & No \\
\hline & Cicchetti, 2004) & (Briggs-Gowan M. J. et al., 2013) & No & Yes \\
\hline \multirow{2}{*}{$\begin{array}{l}\text { Ages \& Stages } \\
\text { Questionnaire: Social } \\
\text { Emotional (ASQ-SE) }\end{array}$} & (Squires et al., 2010) & (Heo \& Squires, 2012) & No & Yes \\
\hline & & (Hunter \& Lynch, 2013) & No & Yes \\
\hline \multirow{2}{*}{$\begin{array}{l}\text { Denver } \\
\text { Developmental } \\
\text { Screening Test }\end{array}$} & (Frankenburg & $\begin{array}{l}\text { (Darrah, Hodge, Magill-Evans, } \\
\text { \& Kembhavi, 2003) }\end{array}$ & No & Yes \\
\hline & e & $\begin{array}{l}\text { (Biscegli, Polis, Santos, } \\
\text { \& Vicentin, 2007) }\end{array}$ & Yes & Yes \\
\hline
\end{tabular}

Note: Highlighted are the studies that used the measure both in child daycare centers and to discuss possible assessment public policies.

Results showed that 10 screening measures were used in the literature through the past 15 years. Five of them (50\%) presented studies with child daycare centers samples, and 7 (70\%) were used or at least discussed under any kind of assessment policy.

Among these measures found in this search, only three (30\%), were used or discussed on both assessment policies and child daycare centers: 1) the Developmental Indicators for the Assessment of Learning-DIAL (Mardell-Czudnowski \& Goldenberg, 1998); 2) the Ages \& Stages Questionnaire (Squires \& Bricker, 2009) and 3) the Denver Developmental Screening Test (Frankenburg, Dodds, Archer, Shapiro, \& Bresnic, 1992). The results will be discussed using those measures as references trying to answer the question posed by this articlebut not restricted to it. 


\section{Discussion}

The results of the present study showed that three measures presented evidence of its use in child daycare centers and assessment policies. Thus, it is possible to use and incorporate these measures in cost-effective assessment policies that, ultimately, are going to help the public government to develop more effective strategies of education and child care in developing countries. Regardless, the results showed that a larger amount of screening measures were used to discuss assessment policies in health care systems rather than implicated in child daycare centers. This probably occurs because the main purpose of a psychological screening is to detect children with development impairments (Brauner \& Stephens, 2006; Briggs et al., 2012; Hunter \& Lynch, 2013; Jee et al., 2010; Mogasale, Patil, Patil, \& Mogasale, 2012), whereas child daycare centers in developing countries are not always a place for health interventions.

The first measure found by the present research is the Developmental Indicators for the Assessment of Learning-DIAL (Mardell-Czudnowski \& Goldenberg, 1998). The DIAL is a screening measure for children from 2 years and 6 months of age to 5 years and 11 months. It assesses five areas of development: motor, concepts, language, self-help development and social-emotional development. Among those domains, three-motor, concepts and language - are based on child's performance in pre-determined tasks. Whereas the other two are based on teacher's or parent's observations. DIAL is used by several daycare centers and schools in the Head-Start program (Pretti-Frontczak, Kowalski, \& Brown, 2002), which is evidence of its reliability as a screening measure, however it is not clear its psychometric properties in this type of sample. The absence of studies regarding psychometric properties of the DIAL in child daycare centers poses as a challenge to its use in assessment policies.

In terms of cost-effectiveness, the DIAL presents two distinct costs for its assessment: 1) the instruments' cost and 2) skilled worker cost and training. The DIAL's cost for the entire instrument-including forms, parent questionnaires, supplementary material and scoring sheets-is US\$503.90 (price in American dollar) and can be used in 50 children (Pearson Clinical, 2014). However, in several countries such as Brazil (CFP, 2001, 2003), Canada (Canadian Psychological Association, 1994), and even in United States (American Board of Professional Psychology, 2013), psychological assessment of behavioral outcomes based in individual's performance requires certified psychologists. Those professionals are skilled, thus scarce and expensive workers for developing countries. In Brazil, the minimum per hour of a psychologists with specialization in psychometrics is $\mathrm{R} \$ 128.40$ (in Real, Brazilian currency) — or US\$57.32 (CRP-RJ, 2013) according to an estimated relation of US\$xR of 2.24. Each children is supposed to have at least one session of assessment, which means the total estimated cost of US\$67.40/child. The sum of a skilled worker and the value of the instrument can decrease the cost-effective status of the DIAL as a screening measure. Based on those two aspects-unclear psychometric properties in child daycare centers, and demand of skilled workers to conduct assessment; the DIAL is probably not adequate as a cost-effective screening measure in childcare programs.

The second screening instrument retrieved in the present research is the Ages \& Stages Questionnaire (Squires \& Bricker, 2009) in its third edition (ASQ-3). The ASQ-3 assesses children from 1 month to 5 years and 6 months of age in also five domains of development: communication, gross and fine motor, problem solving and personal-social. Unlike the DIAL, the ASQ-3 is a parent-completed questionnaire and the mere observation of parents is enough to evaluate children. It remained unclear the psychometric properties of the ASQ-3 in a child daycare center sample until the work of Filgueiras et al. (2013). The authors showed that the Brazilian version of the ASQ-3 - called ASQ-BR — had good internal consistency in four of the five domains - with exception of the personal-social domain — and good reliability to assess cognition and motor skills in children attending to Brazilian daycare centers. The questionnaire is a 30-item scale divided in 6 items per domain. This is indeed an advantage to the ASQ-3 because it takes only few minutes to the caregiver to fill the instrument. There are no need of specialized training or skilled worker to assess the child's performance, thus it is not a measure exclusive for psychologists. Regarding the ASQ-3 cost-effectiveness, its total value is US\$275.00 and can be used in 10 children throughout their entire first childhood (Brooks Publishing, 2014). Considering that no skilled worker is needed, the estimate value is US\$27.50/child which is almost five times cheaper than the DIAL, making the ASQ-3 an interesting and cost-effective screening measure.

Regardless, some limitations of the ASQ-3 as a psychological instrument can be highlighted. First, the personal-social domain presented low Cronbach's alpha in both the normative (Squires \& Bricker, 2009) and Filgueiras et al. (2013) data-one of the most important internal consistency indexes in psychometrics (Cohen \& 
Swerdlik, 2009)—which indicates unreliable results based on this particular domain. Several authors tend to say that validity and association of the scale with other variables are statistical indexes limited by the measure's internal consistency (Meier \& Perrig, 2000). Indeed, the Cronbach's alpha can be decreased by the number of items (Dukes, 2005). In the case of the ASQ-3, all its scales are 6-items, which can diminish the value of the alpha. Also, it is expected that the entire set of items is evaluating a single construct, and Filgueiras et al. (2013) showed that the ASQ-3 presented two factors in the personal-social domain using different techniques of factor analysis. These evidence altogether have to be taken into account to explain poor Cronbach's alpha in those scales.

Second, the ASQ-3 is a parent-completed questionnaire and some items just do not fit into child daycare centers reality, so an adaptation maybe required. Finally, the ASQ-3 has no emotional outcomes, limiting the measure to language, reasoning and motor domains. These caveats suggest that the ASQ-3 by itself is not a complete measure, thus needs complements when used in child daycare programs.

Finally, the Denver Developmental Screening Test (Frankenburg et al., 1992) in its second edition—called Denver II—was studied in a childcare center environment by Biscegli et al. (2007). The Denver II presents the most spread age range among the three retrieved screening measures assessing children from 2 weeks to 6 years of age. However, it assesses four developmental domains of preschoolers: personal-social, language, fine and gross motor-one less than the ASQ-3 and DIAL. The measure was developed both for clinical and educational follow up of children, thus any early childhood professional is able to use the Denver II (Frankenburg et al., 1992). Despite of good age range, the Denver II, like the DIAL, does not present specific psychometric properties for childcare center samples. The Biscegli et al. (2007) study was conducted with the purpose of screening impaired children with poor nutritional conditions, not concerning with adaptation or standardization of the measure in Brazil. Another problem is that it needs at least a trained professional to conduct the behavioral assessment since its items rely on children's performance. In terms of cost, the Denver II is the cheapest measure found amongst the retrieval material: US\$0.50/child (Denver Developmental Materials, 2014). However, the cost of a trained professional cannot be forgotten, increasing its total value to, at least, US\$57.82-taking into account that all children complete the questionnaire in a single session. This last issue makes the Denver II comparable to the DIAL, thus making difficult to developing countries to develop assessment policies based on this measure.

Recently, the Minnesota Department of Public Health excluded the Denver II as an indicated measure for screening in early childhood due to its inability to fulfill the criteria established by the organization for screening practices (Minnesota Department of Health, 2012), whereas the same institution indicates the ASQ-3 to the same purposes. Based on the results and discussions regarding the three retrieved screening measures, the ASQ-3 seems to be the most cost-effective and reliable measure to childcare centers, however it still needs further studies to improve internal consistency of the personal-social scale. An interesting alternative is to study the psychometric properties of the Ages \& Stages Questionnaire: Social Emotional-ASQ: SE (Squires, Bricker, Heo, \& Twombly, 2010) in child daycare center samples.

Answering the raised questions of the present study, the ASQ-3 is the only measure that was studied in a child daycare center sample. Indeed it presented good psychometric properties, with exception of the personal-social domain. Due to implications of training and skilled professionals to deal with behavior assessment using the DIAL and Denver-II, also the only screening measure recommended to evaluate cognitive development in early childhood was also the ASQ-3, nevertheless, because of its limitations in terms of internal consistency, there is no instrument capable of providing a complete assessment policy in the child daycare center environment.

Regarding cost-effectiveness, the ASQ-3 total estimated value was US\$27.50, whereas the DIAL was US\$67.40 and the Denver II was US\$57.82. Both the last two measures demand a skilled worker, which makes them less cost-effective in terms of screening measures. Cost wise, it is recommended to educationalists and child psychologists in developing countries to look for measures that do not need extensive training to reduce cost of assessment. However, if there are no budget limits, then other criteria should be adopted to choose between either assessment measures.

\section{Challenges for Psychological Assessment in Brazilian Childcare Centers}

Some educationalists in Brazil believe that health and child care are dissociate things. In a qualitative research, educationalists from a Brazilian child daycare center were interviewed about their knowledge and other va- 
riables associated with children’s health and education (Alves \& Veríssimo, 2007). The results showed that, despite of thinking that it is important to look upon a child's health, in the educationalists opinion it is not their job to intervene or promote health programs. According to Alves and Veríssimo (2007), this phenomenon happens in several daycare centers in Brazil and it is related to excessive work and lack of training. Despite of some attempts to integrate education and health care (for example, Gonçalves, Catrib, Vieira, \& Vieira, 2008), educationalists present different views regarding childcare policies. For this reason they prefer to allocate their resources only on educational practices such as teaching colors and animal names, and practicing affective/emotional social interactions with their children, whereas children's psychopathologies and cognitive domains are either treated by other professionals or neglected.

De Oliveira and Miguel (2012) discuss the advances of a new Brazilian law for educational practices showing that the government is indeed concerned with four aspects of early childhood development: cognition, motor skills, emotion and social interactions. However, they question the concept of childhood from the cognitive sciences using their political beliefs in the place of empirical evidences. For them, children's performance on tasks are not to be a concern for two reasons: 1) each individual has its own learning path, so a child has to be respected and celebrated in her own progress regardless of the development of her peers; and 2) concerns about performance are for adults in a capitalistic environment, whereas school is a place to exercise play and free will, without the weight of the capitalism concept of success on children's shoulder (Oliveira \& Miguel, 2012).

In extension of this argument, Neves and Moro (2013) question psychological assessment in educational settings such as child daycare centers. These authors state that assessment measures in psychology were developed and exist due to a demand of the capitalism for selecting the best workers to each position in this economic system. They believe that psychological measurement are used in a good intent-to help people—but, ultimately, instruments are used to stigmatization, prejudice and labeling, which is their big concern in Brazil (Neves \& Moro, 2013). From these authors' point of view, the alternative method to assess quality of child care and development of children in child daycare centers is: each educationalist has to have the freedom to create his own measure based on the educational practices they developed. This essentially means that standardized psychological assessment should be replaced by individual qualitative methods of evaluation not concerning with other children's progress, on the opposite, focusing only in the child in question. Nonetheless, it is unclear if these authors rely or are aware of what means evidence-based practices in child development.

Several authors from different fields of science warn to the danger of mixing political beliefs and scientific research. It is undeniable that politics play a role in science, but a careful researcher will at least try to avoid it. Qualitative methods and political views in scientific research are indeed problematic. Burman (1997) suggests that social and culture scientists using qualitative research in psychology poses themselves in higher moral grounds because they argue being aware of the political implications of quantitative researches. However, the author stresses that those researchers seem to forget that, like in any balance, when you try to equilibrate by weighting to the other side, the danger to exaggerate is big.

Systematically reviewing articles using qualitative methods, Burman (1997) found several methodological flaws — such as using percentage and other quantitative techniques wrongly—-that posed threats to their conclusions exactly because they exaggerated in trying to diminish quantitative and empirical findings rather than suggest their own novel hypotheses to be empirically tested (Burman, 1997). Indeed, a well-designed qualitative research can bring pivotal contributions to science, but it is clear that both methods should be combined in order to support human and social sciences to evolve (Onwuegbuzie \& Leech, 2005; Randall \& Phoenix, 2009).

Authors like De Oliveira and Miguel (2012) and Neves and Moro (2013) in Brazilian education clearly base their discussions in three foundations: qualitative research with questionable methodologies, laws_-being a law does not make something right or empirically acceptable—and authorities' or theorists' arguments, rather than empirical evidence. This political view in modern science, particularly in psychology and education, is problematic. For example, the physicist Alan Sokal showed how claims of an authority in a field of science can be misleading without proper empirical evidence (Sokal, 1996a, 1996b). Other researchers also showed how political beliefs and non-empirical statements are dangerous to other sciences such as biology and neurosciences (Dawkins, 1998), which brings back the importance of rigorous qualitative and quantitative methods of assessment to achieve evidence-based findings and practices.

\section{Conclusion}

The present study finds one screening measure that is cost-effective and has good psychometric properties in a 
childcare center sample: the ASQ-3. Nonetheless, its personal-social scale is still in need of improvement. Emotional aspects of development also need reliable instruments. Developing countries would benefit from such screening measures if further studies of psychometric properties provide more reliable tools to assess cognition in preschoolers. Regardless, two important issues are raised in this article's discussion using Brazil as an example: 1) training and excessive work of educationalists in child daycare centers; and 2) psychological screening measures are focused on cognition and impaired development, thus they do not extinguish the demand for other instruments to assess educational practices, curricula, space, furniture, staff and other variables linked to quality of care in early childhood.

\section{Acknowledgements}

This research was supported by grant \#203546/2013-0 from the National Council for Scientific and Technological Development (CNPq), Federal Government, Brazil.

\section{References}

Ação Educativa (2012). Educação Infantil: Déficit de atendimento no município de São Paulo-Creche para Todos. São Paulo. http://www.acaoeducativa.org.br/index.php/educacao/51-acao-na-justica/2385-casos-juridicos

Achenbach, T., \& Rescorla, L. (1991). The Manual for the ASEBA School-Age Forms \& Profiles. Burlington: University of Vermont, Research Center for Children, Youth, and Families.

Alves, R. C. P., \& Veríssimo, M. D. L. Ó. R. (2007). Os educadores de creche e o conflito entre cuidar e educar. Revista Brasileira de Crescimento E Desenvolvimento Humano, 17, 13-25.

American Board of Professional Psychology (2013). Psychological Testing Certification. Chicago, IL. http://www.abpp.org/i4a/pages/index.cfm?pageid=3285

Arnett, J. (1989). Caregivers in Day-Care Centers: Does Training Matter? Journal of Applied Developmental Psychology, 10, 541-552. http://dx.doi.org/10.1016/0193-3973(89)90026-9

Bergman, A. B. (1980). Project Head Start: A Legacy of the War on Poverty. Archives of Pediatrics \& Adolescent Medicine, 134, 1007. http://dx.doi.org/10.1001/archpedi.1980.02130220081043

Biscegli, T. S., Polis, L. B., dos Santos, L. M., \& Vicentin, M. (2007). Avaliação do estado nutricional e do desenvolvimento neuropsicomotor em crianças freqüentadoras de creche. Revista Paulista de Pediatria, 25, 337-342.

Brauner, C. B., \& Stephens, C. B. (2006). Estimating the Prevalence of Early Childhood Serious Emotional/Behavioral Disorders: Challenges and Recommendations. Public Health Reports, 121, 303-310.

http://www.pubmedcentral.nih.gov/articlerender.fcgi?artid=1525276\&tool=pmcentrez\&rendertype=abstract

Briggs, R. D., Stettler, E. M., Silver, E. J., Schrag, R. D. A., Nayak, M., Chinitz, S., \& Racine, A. D. (2012). Social-Emotional Screening for Infants and Toddlers in Primary Care. Pediatrics, 129, e377-e384.

http://dx.doi.org/10.1542/peds.2010-2211

Briggs-Gowan, M. J., \& Carter, A. S. (2008). Social-Emotional Screening Status in Early Childhood Predicts Elementary School Outcomes. Pediatrics, 121, 957-962. http://dx.doi.org/10.1542/peds.2007-1948

Briggs-Gowan, M. J., Carter, A. S., Irwin, J. R., Wachtel, K., \& Cicchetti, D. V. (2004). The Brief Infant-Toddler Social and Emotional Assessment: Screening for Social-Emotional Problems and Delays in Competence. Journal of Pediatric Psychology, 29, 143-155. http://dx.doi.org/10.1093/jpepsy/jsh017

Briggs-Gowan, M. J., Carter, A. S., McCarthy, K., Augustyn, M., Caronna, E., \& Clark, R. (2013). Clinical Validity of a Brief Measure of Early Childhood Social-Emotional/Behavioral Problems. Journal of Pediatric Psychology, 38, 577-587. http://dx.doi.org/10.1093/jpepsy/jst014

Brooks Publishing (2014). Price Table for the Ages and Stages Questionnaire (3rd ed.). http://www.brookespublishing.com/resource-center/screening-and-assessment/asq/asq-3/

Burman, E. (1997). Minding the Gap: Positivism, Psychology, and the Politics of the Qualitative Methods. Journal of Social Issues, 53, 785-801. http://dx.doi.org/10.1111/j.1540-4560.1997.tb02461.x

Campos, M. M., Fullgraf, J., \& Wiggers, V. (2006). A qualidade da educação infantil brasileira: Alguns resultados de pesquisa. Cadernos de Pesquisa, 36, 87-128. http://dx.doi.org/10.1590/S0100-15742006000100005

Canadian Psychological Association (1994). Recommendations by the Canadian Psychological Association for Improving the North American Safeguards that Help Protect the Public Against Test Misuse. London, ON.

http://www.cpa.ca/cpasite/userfiles/Documents/publications/TestMisuse.pdf

CFP (2001). Resolução No 25/2001-Conselho Federal de Psicologia. Brazil. 
http://www.crprs.org.br/upload/legislacao/legislacao46.pdf

CFP (2003). Resolução No 002/2003-Conselho Federal de Psicologia. Brazil. http://pol.org.br/legislacao/pdf/resolucao2003_2.pdf

Charafeddine, L., Sinno, D., Ammous, F., Yassin, W., Al-Shaar, L., \& Mikati, M. A. (2013). Ages and Stages Questionnaires: Adaptation to an Arabic Speaking Population and Cultural Sensitivity. European Journal of Paediatric Neurology: EJPN : Official Journal of the European Paediatric Neurology Society, 17, 471-478. http://dx.doi.org/10.1016/j.ejpn.2013.03.001

Christian, K., Morrison, F. J., \& Bryant, F. B. (1998). Predicting Kindergarten Academic Skills: Interactions among Child Care, Maternal Education, and Family Literacy Environments. Early Childhood Research Quarterly, 13, 501-521. http://dx.doi.org/10.1016/S0885-2006(99)80054-4

Claessens, A. (2012). Kindergarten Child Care Experiences and Child Achievement and Socioemotional Skills. Early Childhood Research Quarterly, 27, 365-375. http://dx.doi.org/10.1016/j.ecresq.2011.12.005

Cleveland, G., \& Krashinsky, M. (1998). The Benefits and Costs of Good Child Care (p. 103). Scarborough: Department of Economics, University of Toronto at Scarborough.

Cohen, R. J., \& Swerdlik, M. (2009). Psychological Testing and Assessment (7th ed.). New York: McGraw-Hill Humanities/Social Sciences/Languages.

Cooper, J. L. (2009). Social-Emotional Development in Early Childhood What Every Policymaker Should Know. Columbia, NY: National Center for Children in Poverty.

Côté, S. M., Mongeau, C., Japel, C., Xu, Q., Séguin, J. R., \& Tremblay, R. E. (2013). Child Care Quality and Cognitive Development: Trajectories Leading to Better Preacademic Skills. Child Development, 84, 752-766. http://dx.doi.org/10.1111/cdev.12007

CRP-RJ (2013). Tabela de Honorários dos Psicólogos [Price Table of Psychologists]. Rio de Janeiro. http://www.crprj.org.br/servicos/Tabela-Honorários-Psicólogos-2014-CFP-FENAPSI.pdf

Darrah, J., Hodge, M., Magill-Evans, J., \& Kembhavi, G. (2003). Stability of Serial Assessments of Motor and Communication Abilities in Typically Developing Infants-Implications for Screening. Early Human Development, 72, 97-110. http://dx.doi.org/10.1016/S0378-3782(03)00027-6

Dawkins, R. (1998). Postmodernism Disrobed. Nature, 394, 141-143. http://dx.doi.org/10.1038/28089

de Barros, R. P., de Carvalho, M., Franco, S., Mendonça, R., \& Rosalém, A. (2011). Uma avaliação do impacto da qualidade da creche no desenvolvimento infantil. Pesquisa E Planejamento Econômico, 41, 213-232.

de Oliveira, D. R., \& Miguel, A. S. B. (2012). A nova concepção de creche pós-LDB (Lei de Diretrizes e Bases da Educação Nacional-Lei no 9.394/96) [The Post-LDB Conception of Daycare-Law 9.394/96]. Revista Fafibe On-Line, 5, 1-8.

Denver Developmental Materials (2014). Pricing Update Denver II. http://denverii.com/denverii/

Diamond, A. (2010). The Evidence Base for Improving School Outcomes by Addressing the Whole Child and by Addressing Skills and Attitudes, Not Just Content. Early Education and Development, 21, 780-793. http://dx.doi.org/10.1080/10409289.2010.514522

Diamond, A., Barnett, W. S., Thomas, J., \& Munro, S. (2007). Preschool Program Improves Cognitive Control. Science, 318, 1387-1388. http://dx.doi.org/10.1126/science.1151148

Dukes, K. A. (2005). Cronbach’s Alpha. In P. Armitage, \& T. Colton (Eds.), Encyclopedia of Biostatistics (pp. 55-68). Chichester: John Wiley \& Sons, Ltd.

Epstein, M. H., \& Nelson, J. R. (2006). Early Childhood Behavior Problem Screening Scale. Lincoln, NE: Center for At-Risk Children's Services, University of Nebraska.

Filgueiras, A., Pires, P., Maissonette, S., \& Landeira-Fernandez, J. (2013). Psychometric Properties of the Brazilian-Adapted Version of the Ages and Stages Questionnaire in Public Child Daycare Centers. Early Human Development, 89, 561-576. http://dx.doi.org/10.1016/j.earlhumdev.2013.02.005

Frankenburg, W. K., Dodds, J. B., Archer, P., Shapiro, H., \& Bresnic, B. (1992). Denver II Technical Manual (2nd ed.). Denver, CO: Denver Developmental Materials.

Gadow, K. D., \& Sprafkin, J. (1997). Early Childhood Inventory: Norms Manual. Stony Brook: Checkmate Plus.

Gleason, M. M., Zeanah, C. H., \& Dickstein, S. (2010). Recognizing Young Children in Need of Mental Health Assessment: Development and Preliminary Validity of the Early Childhood Screening Assessment. Infant Mental Health Journal, 31, 335-357. http://dx.doi.org/10.1002/imhj.20259

Goelman, H., Forer, B., Kershaw, P., Doherty, G., Lero, D., \& LaGrange, A. (2006). Towards a Predictive Model of Quality in Canadian Child Care Centers. Early Childhood Research Quarterly, 21, 280-295.

http://dx.doi.org/10.1016/j.ecresq.2006.07.005 
Gonçalves, F. D., Catrib, A. M. F., Vieira, N. F. C., \& Vieira, L. J. E. de S. (2008). A promoção da saúde na educação infantil [Health Promotion in Primary School]. Interface-Comunicação, Saúde, Educação, 12, 181-192. http://dx.doi.org/10.1590/S1414-32832008000100014

Goodman, A., \& Sianesi, B. (2005). Early Education and Children's Outcomes: How Long Do the Impacts Last? Fiscal Studies, 26, 513-548. http://dx.doi.org/10.1111/j.1475-5890.2005.00022.x

Gudaitis, J. L. (2002). The Early Childhood Inventory-4 and Child Symptom Inventory-4 as Screening Measures for Pervasive Developmental Disorders: A Validity Study. ETD Collection for Pace University, Paper AAI3. http://digitalcommons.pace.edu/dissertations/AAI3065557

Hackman, D. A., \& Farah, M. J. (2009). Socioeconomic Status and the Developing Brain. Trends in Cognitive Sciences, 13, 65-73. http://dx.doi.org/10.1016/j.tics.2008.11.003

Harms, T., \& Clifford, R. M. (1980). Early Childhood Environment Rating Scale. New York: Teachers College Press.

Harms, T., Cryer, D. R., \& Clifford, R. M. (1990). Infant/Toddler Environment Rating Scale. New York: Teachers College Press.

Heckman, J. J. (2006). Skill Formation and the Economics of Investing in Disadvantaged Children. Science, 312, $1900-1902$. http://dx.doi.org/10.1126/science.1128898

Heo, K. H., \& Squires, J. (2012). Cultural Adaptation of a Parent Completed Social Emotional Screening Instrument for Young Children: Ages and Stages Questionnaire-Social Emotional. Early Human Development, 88, 151-158. http://dx.doi.org/10.1016/j.earlhumdev.2011.07.019

Herbst, C. M., \& Tekin, E. (2010). Child Care Subsidies and Child Development. Economics of Education Review, 29, 618638. http://dx.doi.org/10.1016/j.econedurev.2010.01.002

Hunter, L. R., \& Lynch, B. A. (2013). Impact of Implementing Mental Health Screening by Mail with a Primary Care Management Model. Journal of Primary Care \& Community Health, 5, 9-13. http://dx.doi.org/10.1177/2150131913484340

Instituto Brasileiro de Geografia e Estatística (2012). Pesquisa Nacional por Amostra de Domicílios [National Research by Population Sample]. Brasília.http://www.ibge.gov.br/home/estatistica/populacao/trabalhoerendimento/

Jee, S. H., Conn, A. M., Szilagyi, P. G., Blumkin, A., Baldwin, C. D., \& Szilagyi, M. A. (2010). Identification of SocialEmotional Problems among Young Children in Foster Care. Journal of Child Psychology and Psychiatry, 51, $1351-1358$. http://dx.doi.org/10.1111/j.1469-7610.2010.02315.x

Juneja, M., Mohanty, M., Jain, R., \& Ramji, S. (2011). Ages and Stages Questionnaire as a Screening Tool for Developmental Delay in Indian Children. Indian Pediatrics, 49, 457-461. http://dx.doi.org/10.1007/s13312-012-0074-9

Karimi, M., Fallah, R., Dehghanpoor, A., \& Mirzaei, M. (2011). Developmental Status of 5-Year-Old Moderate Low Birth Weight Children. Brain \& Development, 33, 651-655. http://dx.doi.org/10.1016/j.braindev.2010.10.022

Mardell-Czudnowski, C., \& Goldenberg, D. S. (1998). Developmental Indicators for the Assessment of Learning (3rd ed.). San Antonio, TX: Pearson Publishing.

Marsh, R., Gerber, A. J., \& Peterson, B. S. (2008). Neuroimaging Studies of Normal Brain Development and Their Relevance for Understanding Childhood Neuropsychiatric Disorders. Journal of the American Academy of Child and Adolescent Psychiatry, 47, 1233-1251. http://dx.doi.org/10.1097/CHI.0b013e318185e703

McKey, R. H., Condelli, L., Ganson, H., Barrett, B. J., McConkey, C., \& Plantz, M. C. (1985). The Impact of Head Start on Children, Families and Communities. Head Start Synthesis Project, Washington DC: U.S. Government Printing Office.

McLoyd, V. C. (1998). Socioeconomic Disadvantage and Child Development. The American Psychologist, 53, $185-204$. http://www.ncbi.nlm.nih.gov/pubmed/9491747 http://dx.doi.org/10.1037/0003-066X.53.2.185

Meier, B., \& Perrig, W. J. (2000). Low Reliability of Perceptual Priming: Consequences for the Interpretation of Functional Dissociations between Explicit and Implicit Memory. The Quaterly Journal of Experimental Psychology, 53, 212-233.

Minnesota Department of Health (2012). Developmental and Social-Emotional Screening of Young Children (0-6 Years of Age) in Minnesota. Minnesota. http://www.health.state.mn.us/divs/fh/mch/devscrn/criteria.html

Mogasale, V. V., Patil, V. D., Patil, N. M., \& Mogasale, V. (2012). Prevalence of Specific Learning Disabilities among Primary School Children in a South Indian City. Indian Journal of Pediatrics, 79, 342-347.

http://dx.doi.org/10.1007/s12098-011-0553-3

Najman, J. M., Heron, M. A., Hayatbakhsh, M. R., Dingle, K., Jamrozik, K., Bor, W., O’Callaghan, M. J., \& Williams, G. M. (2008). Screening in Early Childhood for Risk of Later Mental Health Problems: A Longitudinal Study. Journal of Psychiatric Research, 42, 694-700. http://dx.doi.org/10.1016/j.jpsychires.2007.08.002

Nelson, R., Epstein, M., Griffith, A., \& Hopper, J. (2007). Factor Structure, Internal Consistency, and Interrater Reliability of the Early Childhood Behavior Problem Screening Scale. Topics in Early Childhood Special Education, 27, 148-154.

http://dx.doi.org/10.1177/02711214070270030501 
Neves, V. F. A., \& Moro, C. (2013). Avaliação na educação infantil: Um debate necessário [Assessment in Child Education: A Necessary Debate]. Estudos Em Avaliação Educacional, 24, 272-302.

Nunnally, J., \& Bernstein, I. (1994). Psychometric Theory (3rd ed.). New York: McGraw-Hill.

Onwuegbuzie, A. J., \& Leech, N. L. (2005). On Becoming a Pragmatic Researcher: The Importance of Combining Quantitative and Qualitative Research Methodologies. International Journal of Social Research Methodology, 8, 375-387. http://dx.doi.org/10.1080/13645570500402447

Pearson Clinical (2014). Price Table. Developmental Indicators for the Assessment of Learning (3rd ed.). http://www.pearsonclinical.com/education/products/100000642/developmental-indicators-for-the-assessment-of-learning-t hird-edition-dial-3.html

Peter, J. P., \& Churchill, G. A. (1986). Relationships among Research Design Choices and Psychometric Properties of Rating Scales: A Meta-Analysis. Journal of Marketing Research, 23, 1-10. http://dx.doi.org/10.2307/3151771

Phillipsen, L. C., Burchinal, M. R., Howes, C., \& Cryer, D. (1997). The Prediction of Process Quality from Structural Features of Child Care. Early Childhood Research Quarterly, 12, 281-303. http://dx.doi.org/10.1016/S0885-2006(97)90004-1

Pretti-Frontczak, K., Kowalski, K., \& Brown, R. D. (2002). Preschool Teachers' Use of Assessments and Curricula: A Statewide Examination. Exceptional Children, 69, 109-123.

Ramey, C. T., Collier, A. M., Sparling, J. J., Loda, F. A., Campbell, F. A., Ingram, D. L., \& Finkelstein, N. W. (1984). The Carolina Abecedarian Project: A Longitudinal and Multidisciplinary Approach to the Prevention of Developmental Retardation. North Carolina University Press.

Randall, W. L., \& Phoenix, C. (2009). The Problem with Truth in Qualitative Interviews: Reflections from a Narrative Perspective. Qualitative Research in Sport and Exercise, 1, 125-140. http://dx.doi.org/10.1080/19398440902908993

Rennie, D. A. C., Bull, R., \& Diamond, A. (2004). Executive Functioning in Preschoolers: Reducing the Inhibitory Demands of the Dimensional Change Card Sort Task. Developmental Neuropsychology, 26, 423-443. http://dx.doi.org/10.1207/s15326942dn2601_4

Reynolds, A. J., Temple, J. A., Robertson, D. L., \& Mann, E. A. (2002). Age 21 Cost-Benefit Analysis of the Title I Chicago Child-Parent Centers. Educational Evaluation and Policy Analysis, 24, 267-303. http://dx.doi.org/10.3102/01623737024004267

Rolnick, A., \& Grunewald, R. (2003). Early Childhood Development : Economic Development with a High Public Return (pp. 6-12). Minneapolis: The Federal Reserve Bank of Minneapolis.

Sarmiento Campos, J. A., Squires, J., \& Ponte, J. (2011). Universal Developmental Screening: Preliminary Studies in Galicia, Spain. Early Child Development and Care, 181, 475-485. http://dx.doi.org/10.1080/03004430903458007

Scarr, S., Eisenberg, M., \& Deater-Deckard, K. (1994). Measurement of Quality in Child Care Centers. Early Childhood Research Quarterly, 9, 131-151. http://dx.doi.org/10.1016/0885-2006(94)90002-7

Sokal, A. D. (1996a). A Physicist Experiments with Cultural Studies. Lingua Franca, 4. http://www.physics.nyu.edu/faculty/sokal/lingua_franca_v4/lingua_franca_v4.html

Sokal, A. D. (1996b). Transgressing the Boundaries: Toward a Transformative Hermeneutics of Quantum Gravity. Social Text, 46-47, 217-252. http://dx.doi.org/10.2307/466856

Sprafkin, J., Volpe, R. J., Gadow, K. D., Nolan, E. E., \& Kelly, K. (2002). A DSM-IV-Referenced Screening Instrument for Preschool Children: The Early Childhood Inventory-4. Journal of the American Academy of Child and Adolescent Psychiatry, 41, 604-612. http://dx.doi.org/10.1097/00004583-200205000-00018

Squires, J., \& Bricker, D. (2009). Ages and Stages Questionnaire (ASQ): A Parent Completed Child Monitoring System (3rd ed.). Baltimore, MD: Brooks Publishing Company.

Squires, J., Bricker, D., Heo, K., \& Twombly, E. (2010). Ages \& Stages Questionnaires: Social Emotional: A Parent-Completed, Child-Monitoring System for Social Emotional Behaviors. Baltimore, MD: Paul H. Brookes Publishing.

Talen, M. R., Stephens, L., Marik, P., \& Buchholz, M. (2007). Well-Child Check-Up Revised: An Efficient Protocol for Assessing Children's Social-Emotional Development. Families, Systems, \& Health, 25, 23-35. http://dx.doi.org/10.1037/1091-7527.25.1.23

Waddell, D. D. (1980). The Stanford-Binet: An Evaluation of the Technical Data Available since the 1972 Restandardization. Journal of School Psychology, 18, 203-209. http://dx.doi.org/10.1016/0022-4405(80)90060-6

Wechsler, D. (1989). Wechsler Preschool and Primary Scale of Intelligence-Revised. San Antonio, TX: The Psychological Corporation. 
Scientific Research Publishing (SCIRP) is one of the largest Open Access journal publishers. It is currently publishing more than 200 open access, online, peer-reviewed journals covering a wide range of academic disciplines. SCIRP serves the worldwide academic communities and contributes to the progress and application of science with its publication.

Other selected journals from SCIRP are listed as below. Submit your manuscript to us via either submit@scirp.org or Online Submission Portal.
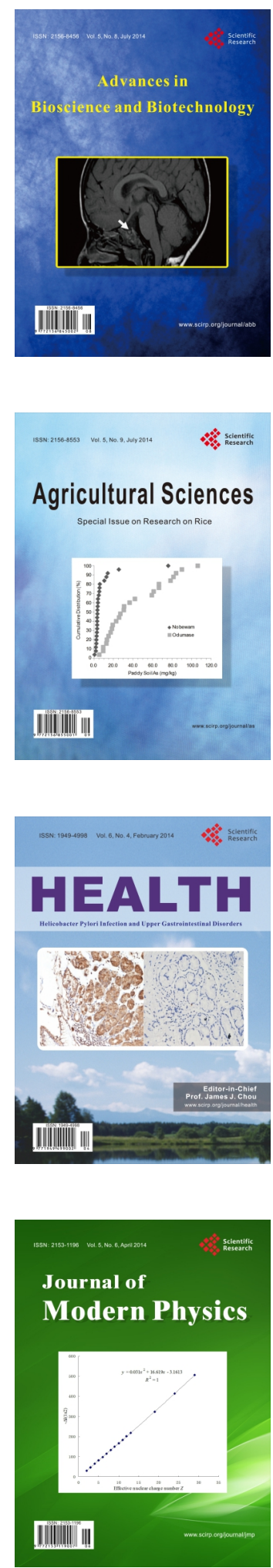
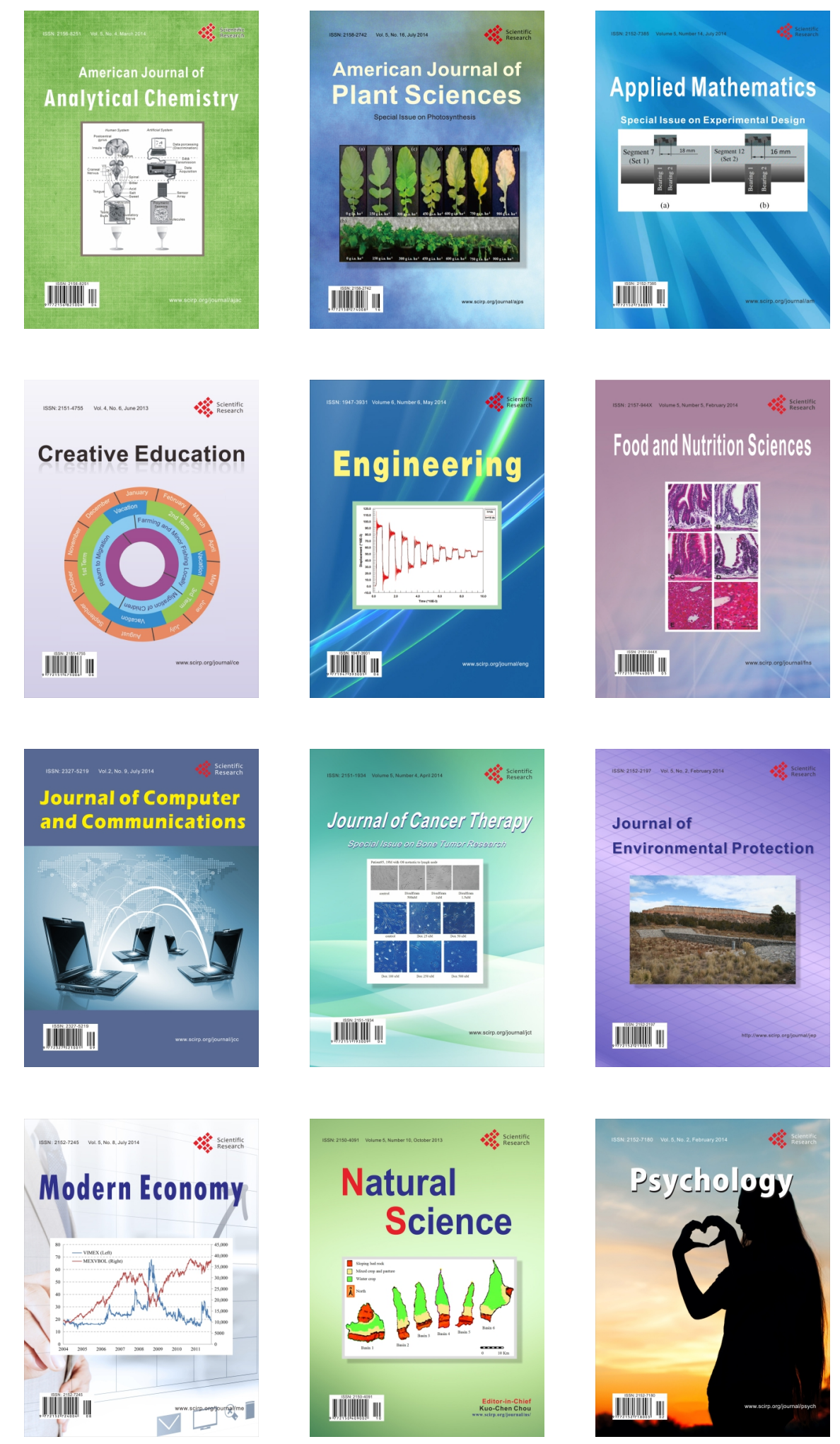